\title{
Some Problems of the Yü-lan-pên-ching (I)
}

\section{Kazuo Okabe}

\section{Introduction}

The Yü-lan-pên-ching 孟蘭盆經, an extremely short work, is included within the Chinese version of Tripitaka, but its original Sanskrit version, if there was one, has not yet been discovered, and no version exists written in Tibetan or other languages. The contents of this work may be briefly summarized as follows: In order to save his suffering mother, who was severely afflicted in her state as a Preta, Maudgalyâyana, a disciple of the Buddha, offered a Basin filled with beautiful and sweet-tasting food, in accordance with the teaching of the Buddha, to all the monks on July 15, day of pravârana (the last day of the summer retreat, during which the monks confess their sins). By the merits of his offering, Maudgalyâyana was able to save his mother; and the Buddha, moreover, emphasized that the merits of any offering on July 15, are not limited to only one's parents in the present life, but extend to those over a period of seven genarations.

This Sutra became the basis for the Urabon-e or Celebration of the

(1) Tsung-mi 宗密, in his commentary, Yü-lan-pên-ching-shu 孟蘭盆經疏, says that there were three Chinese versions of the Yü-lan-pên-ching (TT. XXX IX. 506c). Many other Catalogues also maintain the same. But the $K^{\prime} a i$. yüan-shih-chiao-lu 開元釋敉錄 says there were only two translations. A critical comparison of the three extant sutras however, clearly reveals that originally there was only one translation of this work, and that the other two either were later translations of the original work, or were the products of another tradition. For more details, see my article in Japanese, "A Historical Study of the Translation of the Yü-lan-pên sûtras," to appear soon in the Shūkyō Kenkyū (Journal of Religious Studies) 宗较研究 
Basin in China and Japan, which has been performed beginning from a very early date. A great number of commentaries have been composed on the Yü-lan-pen-ching, and it is evident that the sûtra has been higly respected in the Buddhism of China and Japan.

Critical historical studies were progressively conducted on the Yü-lanpên-ching beginning from the Meiji Era, and a great number of scholars have contributed studies from various angles on this work. The conditions under which the work was first formulated have become increasingly clarified by the studies of these scholars, but there still are several points on which doubts remain and probrems yet to be solved. Despite the fact that this sûtra has had an important influence in the history of Buddhism, there exists only the Chinese version upon which to refer; one is constantly befronted by this inconvenience in his research, in addition to the fact that foreign scholars have offered no conclusive studies on the sûtra. Studies by Japanese scholars are available scattered throughout works and periodicals, but it is by no means easy to refer to all of these. In view of these facts, I should like to set forth some theories on the Yü-lan-pen-ching, and attempt to clarify some of the problems.

\section{References in the Sûtra-catalogues}

The earliest reference in a catalogue of Buddhist-sûtras to the Yü-lanpên-ching can be found in the Ch'u-san-tsang-chi-chi 出三藏記集 by Sêng-yu 僧祐 (445-518) of the Liang Dynasty. Here it is listed as the Yü-lan-ching 盂蘭經 and its translator as unknown. In the Sui-chung-ching-mu-lu 隋衆經 目錄 by Fa-ching 法經 and the Sui-chung-ching-mu-lu by Yen-tsung 彥琮 of the Sui Dynasty, the Ta-t'ang-nei-tien-lu 大唐內典錄 and the Ta-t'ang-tungchung-ta-ching-ai-sseü-i-ch'ieh-ching-mu-lu 大唐東京大敬愛寺一切經目錄 of the T'ang Dynasty, the title has been corrected to Yü-lan-pên-ching, but its author is still listed as unknown.

The Li-tai-san-pao-chi 歷代三寶紀 by Fei Chang-fan 費長房, however, which was completed around the same time as the two Sui-catalogues concludes that it is a sûtra translated by Dharmarakṣa 法護 of the West- 
ern Hsin, but that all those works which directly succeed the Li-tai-sanpao-chi -such as the Ku-chin-i-ching-t $t^{\prime} u$-chi 古今譯經圖紀, the chronologicalcatalogue 代錄 of the Ta-t'ang-nei-tien-lu, the Ta-chou-k'an-ting-chung-ching -mu-lu 大周刊定衆經目錄 and the Kai-yüan-shih-chiao-lu 開元釋敉錄 have adopted the theory of the Li-tai-san-pao-chi, and completedly ignored the fact that the $C h^{\prime} u$-san-tsang-chi-chi lists its author as unknown. Which of these works has the correct view? In order to answer this question what is important here are the various characteristics of these catalogues, the reliability of their listings, and how, in their contents, they have criticized and evaluated the Li-tai-san-pao-chi. Utilizing the conclusions of their studies on the catalogues, Japanese scholars to the present day have held it advisable that, except for a few exceptions, most of the works translated prior to Kumârajîva noted for the first time in the Li-tai-san-pao-chi, which are not authenticated by reference to earlier catalogues, should be regarded as spurious. The reason, they say, for such errors to be daringly perpetuated in the Li-tai-san-pao-chi, was that, warranted by the historical circumstances of the Sui Dynasty in which the Buddhists were warring with the Taoists, Fei Chang-fang, a Buddhist who wanted to boast of the superiority of Buddhism, was overzealous in his fierce effort to perserve the faith. The distortion of the truth, however, as in the case of the items in the Li-tai-san-pao-chi must be corrected in the light of criticism by historical studies, I feel.

Moreover, the fact that the Yü-lan-pên-ching was not translated by

(2) Cf. Tomójiro Hayashiya, Kyôroku no Kenkŷ̂ 經錄の研究, '(Studies on the Sû tra-catalogues); also, his Iyaku-kyôrui no Kenkyû 異譯經類の研究（A Study on the Different Translations of the Sutras) pp, 35-47, particularly p. 36. In addition. recent research by Dr. Kôgen Mizuno points to the same conclusion.

(3) Among those sûtras whose translators were not known up to that time, and were edited and compiled in the Li-tai-san-pao-chi, 30 were listed as translations by Dharmarakșa. The Yü-lan-pên-ching is one of those thirty sûtras. But it would perhaps be more appropriate to consider that the translator of these sutras is still unknown. A more detailed discussion appears in my article in Japanese, "On the Translations by Dharmarakșa," in JIBS. XI. 1. 
Dharmarakșa, can be ascertained from studies upon his translations, i. e., a comparison with the sutra-catalogues and his individual diction and style. It is interesting to note, however, that all the collections of the Tripitaka have listed Dharmarakșa as the translator of the Yü-lan-pên-ching, and many commentaries, in addition, have upheld this idea.

And Western scholars, referring generally to Nanjo's Catalogue and to the studies by P. C. Bagchi and others, have argued, as an established fact, that Dharmarakșa translated the Yü-lan-pên-ching during the Western Hsin Dynasty. Considerations on the results of recent studies of the history of the translated sutras, however, reveal that such a premise (or established fact) should be carefully re-examined.

\section{The Meaning of "Yü-lan-pên"}

What are the meaning and significance of the words "Yü-lan-pên"? As this problem is very important, the commentators of ancient China had held many different theories, and the scholars of more recent times. have not been able to produce an acceptable conclusion in their studies.

I would therefore like to present the chief theories in their chronological order.

The Yü-lan-pên-ching-tsan-shu 血蘭盆經讚述, said to the oldest transla tion, was recently discovered at the Tun-huang excavations, but a part of its opening section has faded, so that it is difficult to decipher. This very section corresponds to the commentary on the title of the work, but we can assume that the "Yü-lan" is interpreted as “倒懸” (hanging upsidedown), and the "pên" as a ceramic basin. Dr. Keiki Yabuki, in his researches, says that the commentary was a work by Hùe-ching 惠淨 of the

(4) A Catalogue of the Chinese Translation of the Buddhist Tripitaka, p. 78.

(5) Le Canon Bouddhique en Chine (Le Traducteurs et les Traductions), Tome I, p. 109. See also E. J. Eitel, Hand-book of Chinese Buddhism (Tokyo, 1904), pp. 185-6.

(6) TT. LXXXV. 540-3. Pelliot No. 2269, the original manuscript is perserved in the Bibliothèque Nationale. 
Early T'ang Dynasty (578-645). About 150 years after this, Tsung-mi (780 -841) wrote his famous Yü-lan-pên-ching-shu in which he says that "Yülan" is an Indian word meaning "hanging upside-down", and that "pên" is a Chinese word meaning "basin for salvation"; thus, "Yü-lan-pên", he interprets, as "the basin which saves one from the suffering of hanging upside-down." Tsung-mi's interpretation is exactly the same as Hùe-Iing's.

On the other hand, Hsüan-ying 玄應 in his ch-ch'ieh-ching-yin-i 一切經 音義 hold that the correct pronunciation is “Ullambana” 烏藍婆㧝, and that its meaning is "hanging upside-down." Hsüan-ying thus criticized as mistaken the interpretation which separates the "Yü-lan" and the "pên", and holds that the former means "hanging upside-down," and the later "ceramic basin." Yüan-chao 元照 (1048-1116) of the Sung Dynasty wrote the Yü-lan-pên-ching-shu-hsin-chi 孟蘭盆經疏新記 in which he upheld Hsüan-ying's theory that the three characters (Yü-lan-pên) refer to Sanskrit words, but as it seems he did not know how to dispose of the earlier theories, he adopted an attitude of compromise.

Yü-ying 遇榮 also of the Sung Dynasty, in his work Yü-lan-pên-chingshu-hsiao-hêng-ch'ao 孟蘭盆經疏孝衡鈔 holds that the title of the sûtra in Sanskrit is "Buddha-bhâșa-ullambana-muñcana-sûtra" 佛陀你舍烏藍婆㧝門佐 羅素咀纜 and in Chinese, is “覺者說救倒毇器經” that is, “佛說孟蘭盆經”. According to his explanation, “pên" is a dialect word which was read “盆 佐那” in ancient times, but newly read as “門佐羅” “門佐暴” and means “the saving vessel" 救器. It seems, however, that the theory of Yü-ying is the result of his strenuous efforts to interpret "Yü-lan-pên" as a combination of Sanskrit and Chinese letters.

Taking up next the interpretations of recent scholars: In his catalogue, Dr. Nanjô set forth the idea that "there are two meanings in the word

(7) Meisha Yoin 鳴沙餘韻 p. 113.

(8) TT. XXXIX. 506-7.

(9) Shukuzô 縮藏, Ongi-bu 音義部 p. 58.

(10) Zokuzô 續藏, XXXV. 2.

(11) Ibid., XCIV. 4 
"pên," One is that is a transliteration of “bana” 婆㧝, the other is "vessel” 器. This interpretation, however, amounts to no more than a listing of the two interpretations given above of the ancient commentators in China.

Professor Chôtatsu Ikeda, following the lead of Dr. Wogiwara, held that ullambana was originally avalambana, later changed to olambana, and finally settled in its present form as ullambana. Prof. Ikeda illustrated the fact that the tale of "hanging upside-down" quoted by Hsüan-ying was one of the legendary narratives of India. Based upon this premise, he agreed completely with the theory of Hsüan-ying, and asserted that the interpretation of “basin” 盆 or “Saving vessel” was a revision based upon a mistaken interpretation of the Chinese.

Dr. Junjirô Takakusu offered another theory completely different from the former ones. According to him, "Yü-lan-pên" is "Ullumpana", and means "succor" 救濟. He held that "ullumpana" is a special Buddhist technical word, works like the Hui-lin-yin-i 慧林音義 are mistaken, which take it in the sense of ullambana; that as Ullumpana is a word used throughout Pâli Buddhism, and is mentioned in the Mahâvyutpatti, this view is the correct one.

Furthermore, whenever the title "Yü-lan-pên-ching" is translated today into Sanskrit, it is generally either taken as "Ullambana-sûtra," or as "Ullambanapâtra-sûtra."

Various theories, both ancient and new, on the problem of the title of this work have been presented above, but it is still difficult to determine which among these is the correct one. The theory of Hsüan-ying as

(12) Nanjô, loc. cit.

(13) “On the Yü-lan-Pên-Ching” (孟蘭盆經に就いて), in Japanese Shûkyô Kenkyû, N. S. III, pp. 59-64.

（14）“Urabon-e no Igi”（孟蘭盆會の意義, The Significance of the Urabon Cerebration), in Hokke 法華, XXIXX. 7, and Pitaka, June 1940.

(15) Mochizuki Bukkyô Daijiten 望月佛敉大辭典 and Bussho Kaisetsu Daijiten 佛書解說大辭典 adopt the former opinion, while E. Chavannes and W. E. Soothill maintain the latter. 
developed byl Dr. Ikeda seems to be the most reasonable one, but in the original version of the sûtra, there exists no account that Ullambana means “hanging upside-down" 倒懸. The words "hanging upside-down" do not even appear within the sutra; the first time that they are used is in the commentaries on the sûtra. The Sanskrit word Ullambana, moreover, does not exist in any Sanskrit dictionary of today. This fact should serve as evidence that a single example of its usage has not been found in any Sanskrit literature to date.

Thus, the meaning of "Yü-lan-pên" is far from clear. One key which may possibly unlock this problem is either a study of the hitorical changes in phonetics from the Period of Six Dynasties up through the T'ang Dynasty, or a study of the various languages of Central Asia. The solution, it seems, will lie in the utilization of the over-all conclusions of these studies.

(To be cont.)

(16) The only exception can be found in the illustration in Wogiwara's Bonwa Daijiten 梵和大辭典 which takes as its authority the view of Hsüan-ying. 